\title{
Pelayanan Pastoral Kontekstual Sebagai Pendekatan Penginjilan di Desa Rantau Buda Kalimantan Selatan
}

\author{
Harming \\ Sekolah Tinggi Teologi Simpson \\ Email: harming984@gmail.com \\ Ferderika Pertiwi Ndiy \\ Sekolah Tinggi Teologi Simpson \\ Email: thyndiy95@gmail.com
}

\begin{abstract}
:
Contextual Pastoral Services as an Evangelical Approach in Rantau Buda Village in South Kalimantan, this article describes thte alternative proposals related to contextual pastoral servis to the community, in the framework of evangelical. Given the existence of a multicultural society in this context, namely in Rantau Buda, South Kalimantan. To explain the topic, the writer uses descriptive analysis method with a qualitative approach. Based on the results obtained, there are several important points made in contextusl pastoral care as am evangelistic approach, namely by praying and fasting, approaching the local government, cultural introduction, pastoral visitation.
\end{abstract}

Keywords: Contextual Pastoral, Evangelim, Rantau Buda

\begin{abstract}
Abstrak:
Pelayanan Pastoral Kontekstual sebagai Pendekatan Penginjilan di Desa Rantau Buda Kalimantan Selatan, dalam artikel, ini penulis memaparkan alternatif usulan terkait dengan pelayanan pastoral kontekstual kepada Masyarakat, dalam kerangka penginjilan. Mengingat keberadaan masyarakat yang multikultur dalam konteks ini yaitu di Rantau Buda Kalimantan Selatan. Untuk menjelaskan tentang topik tersebut, penulis menggunakan metode deskriptif analisis dengan pendekatan kualitatif. Berdasarkan hasil yang didapatkan, ada beberapa poin penting yang dilakukan dalam pelayanan pastoral kontekstual sebagai pendekatan penginjilan yaitu dengan berdoa dan berpuasa, pendekatan kepada pemerintah setempat, pengenalan budaya, perkunjungan pastoral.
\end{abstract}

Kata Kunci: Pelayanan, Pastoral Kontekstual, Penginjilan, Rantau Buda

\section{Pendahuluan}

Tugas penginjilan merupakan mandat yang diberikan Yesus kepada murid-murid-Nya sebelum Ia naik ke surga, Yesus selalu mengingatkan para pengikut-Nya untuk tetap setia memberitakan Injil ke seluruh dunia (Matius 28:19-20). Perintah ini diimplementasikan melalui pelayanan para utusan Injil, yang pergi ke daerah-daerah pedalaman tertentu dengan mengadakan penginjilan sebagai bentuk ketaatan terhadap Amanat Agung itu sendiri.

Petters mengatakan bahwa seorang hamba Tuhan, diwajibkan untuk menyiapkan dirinya sebagai penginjil karena hal tersebut sangat berpengaruh dalam hal merealisasikan Amanat Agung. Bukan itu saja tetapi seorang hamba Tuhan juga harus menjadi sosok pemberita Injil yang berkualitas, serta cakap dalam mengajarkan kebenaran kepada orang lain, 
dan bertanggung jawab dalam tugas pelayanan penginjilan (Peter, 2006, pp. 211-212). Untuk mencapai hal itu, seorang hamba Tuhan perlu melengkapi dirinya melalui pengetahuan dan keterampilan khusus terkait dengan pendekatan penginjilan yang digunakan dalam menunjang pelayanan. Dengan belajar berbagai metode sebagai sarana penginjilan merupakan upaya yang dapat dilakukan seorang hamba Tuhan, salah satu pendekatan yang dapat digunakan ialah pelayanan pastoral kontekstual (Nainggolan, 2016).

Membahas tentang pendekatan penginjilan, ada banyak hal yang bisa menjadi bahan perbincangan atau diskusi. Pendekatan penginjilan yang dipakai oleh orang kristen dalam pelayanan sangat kompleks karena hal tersebut dipengaruhi banyak faktor dan konteks. Menanggapi hal tersebut pelayanan Pastoral Kontekstual merupakan sebuah usulan konkret yang dapat dijadikan sebagai pendekatan penginjilan kepada masyarakat. Konsep pastoral kontekstual ini diperlukan bukan hanya menyentuh kehidupan jemaaat melainkan masyarakat secara umum.

Desa Rantau Budha terletak sekitar 2 km sebelum kantor Kecamatan Sei Durian (jika lewat darat). Menurut cerita tokoh adat, Dumiwol (64 tahun), Pihu (44 tahun, Sekretaris Desa Rantau Budha), dan Martinus (53 tahun, Kepala Desa Rantau Budha). Nama Rantau Budha berasal dari legenda para biksu Budha yang datang ke wilayah ini pada tahun 1970-an untuk berdagang. Keberadaan para penganut Budha pada tahun 2015, sekitar $10 \%$ dari 402 KK, Hindu $10 \%$, Kaharingan $30 \%$, Islam $10 \%$, dan Kristen $40 \%$. Meskipun telah menganut berbagai agama, tetapi mayoritas penduduk Rantau Budha merupakan orang Dusun yang terikat oleh hukum dan aturan adat Dayak Dusun. Sebagian dari mereka merupakan pendatang, seperti Martinus (53 tahun, Kepala Desa Rantau Budha), yang datang dari Labuhan (Barabai) bersama orang tuanya pada tahun 1955 dengan berjalan kaki selama tiga hari tiga malam melalui lembah dan ngarai Pegunungan Meratus.(Etam, 2015) Kepercayaan atau religi yang dimiliki oleh suku dayak di desa Rantau Buda terdiri dari empat komponen yaitu emosi keagamaan, sistem keyakinan, sistem ritus dan upacara, peralatan upacara, serta umat dan kesatuan sosial.(Koentjaraningrat, 1993, pp. 137-142) Pada tahun 1999, seorang Penginjil dari daerah Kalimantan Utara datang ke desa Rantau Buda untuk mengadakan penginjilan. Mengingat ia adalah seorang pendatang, maka banyak hal yang dilakukan oleh penginjil ini untuk bisa beradaptasi sekaligus mengetahui seluk-beluk desa yang menjadi tempat tinggalnya saat itu. Penginjil ini melakukan pelayanan pastoral kontekstual terhadap penduduk atau masyarakat yang belum percaya kepada Tuhan bukan saja agama Kaharingan, tetapi juga agama-agama lainnya di luar Kristen. (Duatan, 2016, p. 24) Dengan demikian, banyak orang yang dimenangkan, dan menjadi percaya kepada Tuhan, meskipun mereka masih terlibat dalam acara-acara kebudayaan dan keagamaan, tetapi itu bukan sebagai suatu kepercayaan lagi bagi mereka tetapi hanya sekedar bepartisipasi untuk menghormati kebudayaan yang ada.

Dalam pembahasan ini, penulis berupaya memaparkan alternatif usulan terkait dengan pelayanan pastoral kontekstual kepada Masyarakat, dalam kerangka penginjilan. Mengingat 
keberadaan masyarakat yang multikultur di Rantau Buda Kalimantan Selatan, sehingga muncul pertanyaan apakah pelayanan pastoral kontesktual yang dilakukan bagian dari penginjilan kepada semua masyarakat? Atau hanya sebatas pelayanan pastoral kepada orang percaya? Permasalahan inilah yang akan dibahas dalam tulisan ini.

\section{Metode}

Metode penelitian yang digunakan dalam penulisan ini adalah menggunakan metode deskriptif analisis dengan pendekatan kualitatif. Menurut pendapat (Moleong, 2017; Nasir, 2005). dalam Whitney, metode penelitian deskriptif ialah pencarian fakta melalui data dengan interpretasi yang tepat. Penelitian ini mempelajari masalah masyarakat, situasi dan kondisi tertentu termasuk tentang relasi, kegiatan-kegiatan, sikap, pandangan-pandangan serta prosesproses yang sedang berlangsung dan dampak dari suatu fenomena, selain itu juga mempelajari tata cara yang berlaku dalam masyarakat. yang akan dideskripsikan dalam penelitian ini ialah Pelayanan Pastoral Kontekstual sebagai Pendekatan Penginjilan di Desa Rantau Buda Kalimantan Selatan. Penggunaan Metode Deskriptif bertujuan untuk memberikan informasi yang komprehensif terkait dengan topik penelitian ini sehingga menghasilkan sebuah pembahasan yang mendalam.

Objek penelitian ini dilaksanakan di Desa Rantau Buda, Kecamatan Sei Durian Kalimantan Tengah. Mendukung data yang akan dideskripsikan, maka penulis mengumpulkan beberapa dokumen terkait dengan topik penelitian ini. Pengumpulan data primer dilakukan dengan observasi langsung ke lokasi penelitian pada bulan Desember 2019, bertujuan untuk menemukan informasi terkait. Selanjutnya, pengumpulan data sekunder ialah mengumpulkan dokumen terkait seperti buku-buku, artikel jurnal yang relevan dengan topik penelitian.

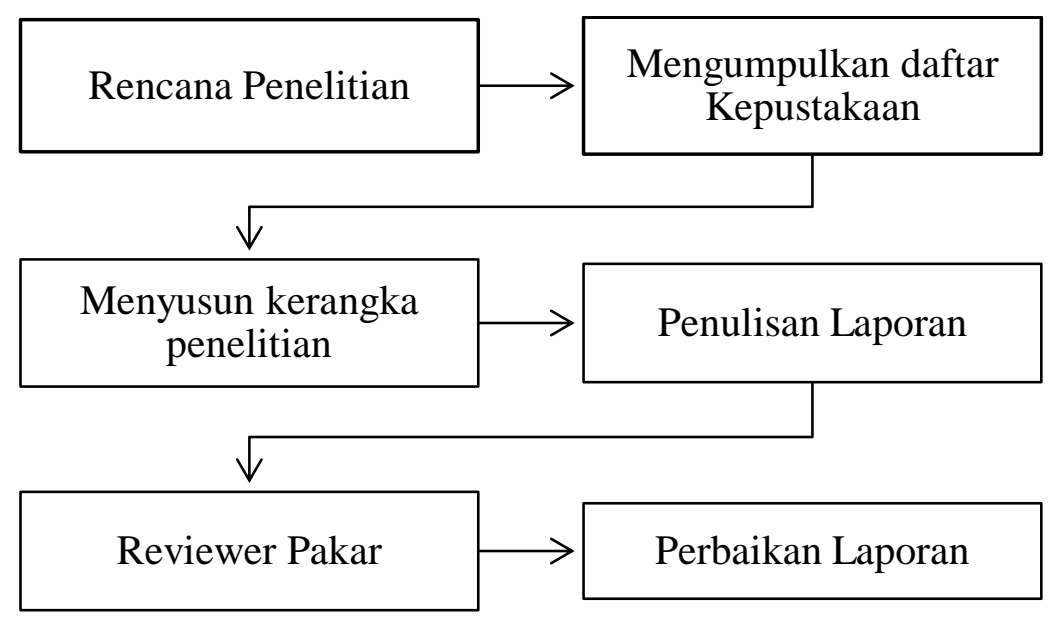

Tabel 1. Proses Penelitian 


\section{Hasil dan Pembahasan}

\section{Tinjauan Umum}

\section{Pelayanan Pastoral Kontekstual}

Pelayanan pastoral kontekstual memiliki kemiripan dengan pelayanan pastoral pada umumnya. Menurut Gerkin (1992), Pelayanan pastoral ialah pelayanan yang dilakukan tanpa pamrih oleh pendeta terhadap jemaat yang bermasalah dan perlu solusi atas persoalan yang dihadapi jemaat tersebut, pusat pelayanannya ialah pendeta serta objek pelayanan ialah jemaat. Menanggapi hal itu Beek (2007, p. 9) mendefinisikan secara hurufiah, yaitu pastoral dalam bahasa Latin "Pastor", Bahasa Yunani "Poimen" apabila kata ini diterjemahkan berarti gembala. Sedangkan kata gembala dikaitkan dalam Yohanes 10 tentang Yesus sebagai gembala yang baik, maka pastoral memiliki arti pelayanan yang dilaksanakan tanpa pamrih. Dengan demikian, pelayanan pastoral berarti pelayanan yang dilakukan oleh hamba Tuhan kepada jemaat yang dilayani. Dengan demikian, pastoral merupakan pelayanan pendampingan yang biasanya dilakukan oleh pendeta kepada jemaat yang dilayaninya. Sedangkan pelayanan pastoral kontekstual memiliki pengertian yang lebih luas lagi secara khusus dalam cakupan pelayanan. Dalam pendapat yang berbeda, Pattison (1998) mengartikan istilah pastoral berkaitan dengan pemeliharaan sekumpulan ternak sebagai analogis bagi seorang pemimpin yang memimpin, mengawasi orang yang dipimpin. Pelayanan pastoral kontekstual menurut Abineno (1998) ialah pelayanan yang bukan hanya dilakukan oleh pendeta, melainkan melibatkan keberadaan jemaat umum. Berdasarkan pendapat tersebut pelayanan pastoral kontekstual ialah pelayanan yang dilakukan oleh orang percaya (pendeta dan jemaat) untuk menolong, mendampingi, mengawasi serta memimpin orang lain untuk bertemu dengan Yesus sang Gembala Agung.

Sebagai seorang penginjil, pelayanan penginjilan merupakan hal utama yang penting yang dilakukan untuk menyampaikan kebenaran Injil khususnya di daerah-daerah pedalaman. Begitu juga dengan Gereja Kemah Injil Indonesia (GKII) Jemaat Rantau Buda yang melakukan pelayanan penginjilan. GKII jemaat Rantau Buda terletak di desa Rantau Buda, Kecamatan Sungai Durian, Kabupaten Kota Baru, Kalimantan Selatan. Di desa Rantau Buda, mayoritas jemaat di sana berasal dari agama suku Kaharingan. Tetapi dengan adanya pelayanan penginjilan yang dilakukan oleh beberapa hamba Tuhan yang telah ditempatkan di tempat tersebut, maka sebagian besar jemaat mulai bertobat dan menyerahkan diri kepada Allah (Duatan, 2016, p. 26).

\section{Penginjilan}

Dalam Alkitab, tidak ditemukan kata penginjilan secara harafiah, namun ketika kata ditinjau dari etimologis, penginjilan berasal dari kata "injil" yang merupakan terjemahan dari

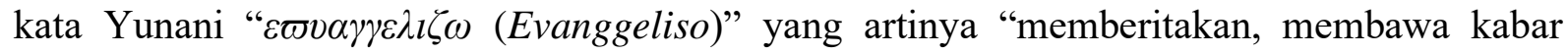


baik, mengumumkan serta memproklamasikan Injil atau juga menjadi pembawa kabar baik dalam Yesus." (Strong t.t.). Menurut Tomatala (2002, p. 24) ketika kata ini dilihat dalam konteks aslinya, kata "evanggeliso" merupakan suatu istilah yang digunakan dalam bidang kemiliteran Yunani. Kata ini mengandung arti "upah yang diberikan kepada pembawa kabar atau berita kemenangan dari medan tempur, atau juga berita kemenangan itu sendiri." Dengan demikian, secara etimologis kata penginjilan dapat diartikan sebagai sesuatu yang memberikan kebaikan atau dengan kata lain suatu kabar baik yang ada didalam Yesus.

Selanjutnya, Tomatala (2002, p. 25) mengatakan bahwa orang Kristen menggunakan kata "evanggeliso" dalam menjelaskan berita tentang karya Kristus Yesus. Selanjutnya Harming (2017) mengungkapkan bahwa penginjilan adalah sebuah tanggung jawab setiap orang percaya kepada Tuhan Yesus untuk memberitakan kabar keselamatan dan penghakiman di dalam Kristus kepada semua umat manusia. Berdasarkan pendapat di atas, penulis menyimpulkan bahwa penginjilan merupakan tugas orang percaya untuk mengumumkan atau menyerukan kabar tentang keselamatan dan penghakiman di dalam Yesus Kristus.

\section{Gambaran Objek Penelitian}

Menurut Bapak Dumiwul, kepala adat desa Rantau Buda, kata "Rantau” artinya aliran sungai yang memanjang. Sedangkan "Buda" merupakan arti dari agama kepercayaan umat Budha. Sekitar tahun 660-an, seorang pendeta Budha datang dari India dan merantau di desa tersebut. Suatu ketika, pendeta tersebut pergi ke sungai Manunggul dan tanpa disadari, selendang dari pendeta Budha itu hanyut di sepanjang sungai Manunggul dari hulu sampai ke Muara Laut (Dumiwul, 2019).

Penduduk Rantau Buda secara umum merupakan suku dayak Dusun Manungul. Menurut Kepala Desa Rantau Buda, Manunggul artinya batu di tengah sungai yang tidak pernah hanyut meskipun air dan kayu yang hanyut dari atas gunung menimpa batu tersebut, namun batu tersebut tidak pernah hancur. Batu Manunggul itu adalah batu keramat yang setiap tahun orang di kampung tersebut selalu memberi sesajian untuk arwah leluhur yang sakti.

Desa Rantau Buda terletak di daerah Kecamatan Sungai Durian, dan secara geografis, Kabupaten Kota Baru adalah salah satu Kabupaten di Provinsi Kalimantan Selatan yang berada di sebuah pulau yang terasing di Kalimantan Selatan. Rantau Buda berbatasan dengan Kecamatan Bakau dan kecamatan Sengayam. Transportasi yang digunakan oleh masyarakat desa Rantau Buda ialah kendaraan beroda dua dan beroda empat melalui jalan darat.

\section{Konteks Sosial}

Desa Rantau Buda daerah yang terletak di dataran rendah dan di dataran tinggi \pm 10 Km dari laut (Salmondia 2020). Selanjutnya, Salmondia menjelaskan bahwa luas desa Rantau Buda 32-33 Ha/M terhitung dari perbatasan Desa Mangka, Desa Bapara, Kecamatan Pamukan 
Barat dan Pamukan Utara sebelah selatan Magalau Hulu, Kecamatan Kelupang Barat sebelah timur desa Manunggul Lama, Kecamatan Sungai Durian.

Keadaan penduduk di desa Rantau Buda bukan saja penduduk asli tetapi banyak penduduk pendatang. Tetapi mereka dianggap sebagai penduduk asli karena sudah puluhan tahun menetap di desa tersebut. Jadi, data statistik yang diperoleh menunjukkan jumlah penduduk desa Rantau Buda sebagai berikut.

\begin{tabular}{|c|l|l|}
\hline No & Asal Penduduk & Jumlah \\
\hline 1 & Penduduk Asli & 730 Orang \\
\hline 2 & Suku Banjar & 265 Orang \\
\hline 3 & Suku Jawa & 55 Orang \\
\hline 4 & Suku Timor (NTT) & 53 Orang \\
\hline 5 & Suku Batak & 69 Orang \\
\hline
\end{tabular}

Tabel 2. Statistik Penduduk Rantau Buda

\section{Konteks Agama dan Budaya}

Desa Rantau Buda merupakan desa yang beraneka ragam, suku, bangsa dan kepercayaan. Bahasa sehari-hari yang digunakan ialah bahasa Dayak Manunggul, bahasa Banjar dan Bahasa Indonesia. Meskipun penduduk di Desa Rantau Buda kebanyakan pendatang, tetapi mereka saling menghormati budaya yang ada. Karena memiliki bayak kebudayaan, maka bagi orang-orang yang belum percaya, mereka menjadikan itu sebagai kepercayaan atau dapat dikatakan sebagai tuhan atau dewa mereka. Dalam setiap acara kebudayaan ataupun kebiasaan-kebiasaan yang sering dilakukan, mereka mengakui bahwa semuanya itu merupakan bentuk penghormatan mereka kepada nenek moyang atau dewa yang mereka sembah. Kepercayaan itu merupakan kepercayaan turun temurun, sehingga disebut kepercayaan leluhur, kepercayaan asli, atau kepercayaan tradisonal (Etam, 2015).

Dari perincian jumlah penduduk di atas, maka penulis menjelaskan jumlah agama yang dianut di desa Rantau Buda, yaitu:

Tabel 2. Statistik Penduduk Rantau Buda

\begin{tabular}{|c|l|l|}
\hline No & Agama & Jumlah \\
\hline 1 & Kristen Protestan & 579 Orang \\
\hline 2 & Kristen Katolikh & 58 Orang \\
\hline 3 & Islam & 346 Orang \\
\hline 4 & Hindu Kaharingan & 189 Orang \\
\hline
\end{tabular}

Berdasarkan data tersebut, masyarakat desa ini memiliki kebudayaan berhubungan dengan kepercayaan yang dimiliki sejak nenek moyang mereka, Adapun kegiatan yang dilakukan oleh penduduk desa Rantau Buda terkait dengan adat kepercayaan sebagai berikut: 


\section{Aru atau Pesta Panen}

Setiap tahun, masyarakat desa Rantau Buda khususnya suku Dayak Dusun Manunggul mengadakan aru atau pesta panen. Menurut adat suku ini, bagi masyarakat yang membuat ladang di setiap akhir tahun harus mengadakan pesta panen. Yaitu pesta sajian yang dibuat dari bermacam-macam rempah untuk pemujaan kepada roh-roh leluhur yang memberi rejeki bagi mereka selama mereka bekerja di ladang. Bapak Dimas selaku masyarakat desa Rantau Buda mengatakan "Jika tiap masyarakat Dayak Dusun Manunggul tidak melibatkan diri dalam pesta panen tahunan, maka mereka akan terkena tulah atau musibah seperti penyakit dan sebagainya."

\section{Upacara Adat}

Selain pesta panen, ada juga beberapa upacara adat yang sering dilakukan oleh suku Dayak Dusun Manunggul sebagai suatu keharusan. Salah satunya ialah mereka mempunyai suatu keyakinan penghayatan kepada roh leluhur yang suci yang turun dari nenek moyang sampai saat ini dan dipelihara serta diyakini dengan pengucapan janji-janji setiap mereka mengadakan pesta. Menurut Atus, salah satu masyarakat desa Rantau Buda menjelaskan bahwa cara mereka melakukan penghayatan tersebut yaitu dengan memperingati hari suci leluhur yang diyakini oleh nenek moyang menurut janji ketika mereka dilahirkan seperti yang dilakukan juga oleh suku Dayak Lerus Meratus (Atus 2019). Dalam melaksanakan upacara penghayatan tersebut, ada beberapa syarat yang harus dilakukan, contohnya menghadirkan seorang dukun sebagai ketua pelaksanaan upacara adat. Tugas dukun ialah mengobati orang sakit pada waktu diperlukan oleh masyarakat. Dan dukun ini akan mengambil haknya sebagai upah pada saat upacara irau atau pesta ulu tahun. Dalam upacara ini disertakan dengan tarian dari anak-anak, kaum muda dan juga orang tua.

\section{Kebiasaan Mistis}

Suku Dayak dusun Manunggul juga mempunyai kebiasaan-kebiasaan mistis yang dianggap sebagai suatu kepercayaan. Ibu Pelem yang merupakan salah satu tokoh masyarakat di desa Manunggul mengatakan bahwa "Jika mereka pergi ke hutan, sebelum itu mereka harus meminta izin kepada Nabi Elias. Nabi Elias adalah nabi yang memelihara semua kayukayu di. Apabila mereka tidak meminta izin terlebih dulu, maka mereka akan tertimpa musibah." (Pelem 2019). Selain itu, ada pula yang dinamakan Nabi Akar. Nabi Akar merupakan nabi yang memelihara seluruh akar-akar kayu yang ada di bumi. Setiap orang dayak yang pergi ke hutan, mereka harus meminta izin terlebih dahulu kepada nabi akar. Jika tidak meminta izin, maka akar-akar pohon di hutan akan mengikat kaki mereka. Mantan kepala adat desa Rantau Buda, Dumiwul, mengatakan "setiap orang dayak yang pergi kehutan untuk berburu, mencari kayu bakar, maupun survey tempat untuk membuat ladang, terlebih dulu harus meminta izin kepada roh-roh yang dihutan atau penghuni hutan yaitu nabi Elias." (Dumiwul 2019a) 


\section{Model Pelayanan Pastoral Kontekstual Sebagai Pendekatan Penginjilan Di Desa Rantau Buda}

Berdoa dan Berpuasa

Doa adalah komunikasi setiap orang percaya dengan Allah yang Maha Tinggi. Ketika seseorang berdoa, disitulah ia menyampaikan ucapan syukur, permohonan, harapan dan permintaannya kepada Allah. Seorang hamba Tuhan yang akan menyampaikan kebenaran tentang Yesus Kristus di mana pun ia berada, yang harus dilakukan terlebih dahulu ialah berdoa. Dalam Efesus 6:11-13, mencatat bahwa: "Kenakanlah seluruh perlengkapan senjata Allah, supaya kamu dapat bertahan melawan tipu muslihat Iblis; karena perjuangan kita bukanlah melawan darah dan daging, tetapi melawan pemerintah-pemerintah, melawan penguasa-penguasa, melawan penghulu-penghulu dunia yang gelap ini, melawan roh-roh jahat di udara. Sebab itu ambillah seluruh perlengkapan senjata Allah, supaya kamu dapat mengadakan perlawan pada hari yang jahat itu dan tetap berdiri, sesudah kamu menyelesaikan segala sesuatu." Sementara dalam Lukas 11:9 mengatakan bahwa: "Oleh karena itu Aku berkata kepadamu: Mintalah, maka kamu akan diberikan kepadamu; carilah, maka kamu akan mendapat; ketoklah, maka pintu akan dibukakan bagimu." Artinya doa harus dinaikan sebagai sumber kekuatan orang percaya dalam melawan setiap serangan baik itu secara fisik maupun kuasa-kuasa kegelapan.

Eime menjelaskan bahwa: "Dengan berdoa, maka persekutuan manusia dengan Allah semakin mendalam. Selain itu manusia mendapatkan kehidupan yang kekal dan jaminan yang mutlak dari Allah yaitu jaminan keselamatan." (Eime 1982, p. 6). Jadi, setiap kehidupan orang percaya harus menerima kepastian yang jelas di dalam Kristus, karena di dalam Kristus, seseorang mempunyai hidup dan jaminan keselamatan yang kekal.

Selain dari berdoa, seorang hamba Tuhan juga harus berpuasa utnuk melepas segala belenggu kelaliman seperti yang tercatat dalam Yesaya 58:6, "Bukan! Berpuasa yang Kukehendaki, ialah supaya engkau membuka belenggu-belenggu kelaliman, dan melepaskan tali-tali kuk, supaya engkau memerdekakan orang yang teraniaya dan mematahkan setiap kuk,". Ketika semua sudah dapat dilepaskan maka ketika seseorang menaikan seruan kepada Tuhan maka Ia akan menjawab seperti yang tertulis dalam Yesaya 58:9, "Pada waktu itulah engkau akan memanggil dan Tuhan akan menjawab, engkau akan berteriak minta tolong dan Ia akan berkata: Ini Aku! ...." Semuanya ini harus dilakukan karena yang menjadi penghalang doa-doa yang tak terjawab ialah dosa-dosa manusia Yesaya 59:2. Menurut pendapat Prince (1994, p. 186) bahwa doa dan puasa merupakan suatu kewajiban gereja yang digambarkan oleh rasul Paulus dalam kitab Efesus, yang merupakan contoh dan teladan bagi setiap orangorang percaya untuk dilanjutkan kepada gereja yang mau bertumbuh dan yang penuh dengan kemuliaan Allah. Selain itu, umat Allah dituntut untuk bertanggungjawab, taat, tunduk, hormat, takluk, dan setia kepada Tuhan. 
Melalui doa dan puasa, orang percaya diberi dorongan agar lebih dekat kepada Tuhan didalam mengerjakan visi dan misi. Doa juga merupakan peperangan rohani orang-orang percaya untuk mengalahkan kuasa Iblis. Tjandra menjelaskan,"doa dapat memulihkan hubungan manusia dengan Allah dan memulihkan bangsa-bangsa dengan kehendak Allah dan mempertahankan hidup dari kekuatan Iblis yang menghancurkan hidup orang percaya." (Tjandra 2009, p. 209).

Pendekatan dengan Pemerintah Setempat

Dalam KBBI, kata pendekatan memiliki arti proses, cara, perbuatan mendekati. Artinya ada suatu cara yang dilakukan agar adanya ikatan persahabatan, atau saling berhubungan satu dengan yang lain. Seorang penginjil, pada dasarnya menciptakan salah satu strategi yang efektif untuk menjangkau orang-orang yang belum mengenal Injil. Melakukan pendekatan dengan tokoh masyarakat atau dengan pemerintah setempat merupakan salah satu cara, seorang penginjil dapat diterima dengan baik disuatu tempat. Sebelum melakukan pendekatan tentunya harus mempersiapkan data pribadi atau kelengkapan mengenai biodata agar jelas dari mana dan tujuan menempati tempat tersebut (Akal 2002, p. 2). Selain dari itu, gaya hidup seorang penginjl atau hamba Tuhan menjadi sorotan yang terpenting. Hamba Tuhan yang akan menyampaikan Injil, harus memiliki cara hidup yang baik, pergaulan yang benar agar dapat mempengaruhi orang-orang sekitar dan dapat diterima dengan baik oleh masyarakat dan juga pemerintah setempat. Sebagai seorang hamba Tuhan yang patuh kepada pemerintah, ia harus menunjukkan teladan buat masyarakat sekitar dengan melakukan kewajibannya sebagai seorang masyarakat seperti yang telah ditetapkan oleh pemerintah. Hal ini dilakukan karena pemerintah adalah hamba Allah atau wakil Allah. Sebagaimana Yesus menjelaskan kepada orang-orang Farisi dalam Markus 12:17, bahwa mereka harus berikan kepada kaisar apa yang wajib mereka berikan dan kepada Allah apa yang wajib mereka berikan kepada Allah. Dengan demikian, bukan hanya teori yang diberikan untuk mengubah sikap seseorang, tetapi contoh yang nyata melalui sikap dan tingkah laku sebagai teladan hidup bagi semua orang yang dipimpin.(Djadi \& Thomassoyan, 2011, p. 79)

\section{Pengenalan Kebudayaan}

Pengenalan kebudayaan merupakan salah satu cara atau strategi yang digunakan sebagai sarana penginjilan untuk memberitakan Injil di suku Dayak Manunggul yang ada di desa Rantau Buda. Menurut Tomatala (1996, p. 73) bahwa dalam Alkitab, Allah bekerja melalui budaya, sehingga Alkitab melukiskan Allah yang menyatakan diri-Nya ke dalam dunia melalui budaya manusia." Suku Dayak Manunggul memiliki suatu kebiasaan yang sering dilakukan oleh masyarakat yaitu melakukan penyembahan kepada nenek moyang di tempat-tempat sepi yang terdapat pohon atau batu-batu yang besar. Dalam penyembahan itu mereka berdoa kepada leluhur mereka agar mendapat pertolongan, perlindungan dan keselamatan. Karena ini sudah menjadi kebiasaan, maka mereka mengangkat ini sebagai 
sebuah kebudayaan masyarakat setempat. Meskipun hal ini sangat bertentangan dengan firman Tuhan, tetapi seorang hamba Tuhan wajib untuk mengetahui kebudayaan-kebudayaan ada. Dengan demikian Injil dapat disampaikan dengan bagaimana hamba Tuhan dapat memperkenalkan Allah sebagai Pencipta yang patut disembah. Seperti dalam Kitab Keluaran 20:3 yang berbunyi: "Jangan ada padamu allah lain di hadapan-Ku." Artinya hanya Allah Sang Pencipta yang layak disembah.

Abineno juga menjelaskan Langit dan bumi diciptakan oleh Allah. Karena itu semua yang ada di dalamnya seperti matahari, bulan, bintang, laut, samudera raya, gunung-gunung dan lainnya tidak boleh disembah oleh manusia dan menganggap bahwa semua ciptaan itu adalah Tuhan (Abineno 1983, p. 19) Seorang penginjil dapat berhasil apabila ia selalu hidup bergaul dengan masyarakat, masuk dalam kebudayaan orang lain, mempunyai prinsip hidup yang tegar, dapat menolong orang lain tanpa memandang ras, suku dan agama. Ketika seorang penginjil akan menyampaikan Injil, sebaiknya ia menyampaikan Injil sesuai budaya setempat. Ketika Yesus menyampaikan Injil pun, Ia masuk ke dalam budaya lokal dan menjelaskan sesuai dengan budaya setempat. Dalam Injil Markus, Yesus menggunakan perumpamaan seorang penabur yang sedang menabur benih, karena masyarakat di sekitar daerah Galilea mayoritas bekerja sebagai petani. Isi berita akan tersampaikan dengan baik apabila sang pembawa berita dapat masuk ke dalam budaya lokal dan menyelaraskan isi berita dengan budaya yang ada tanpa mengurangi makna dari berita tersebut (Harming \& Katarina, 2019, p. 117).

\section{Kunjungan Pastoral}

Selain dari beberapa strategi yang telah disebutkan diatas, penginjilan dapat dilakukan dengan melakukan kunjungan pastoral. Semua ini tidak mudah apabila seorang hamba Tuhan memiliki semangat yang tinggi dan selalu konsisten dalam melayani Tuhan serta seiap menghadapi setiap tantangan yang ada. Tujuan seorang gembala melakukan pelayanan pastoral melalui kunjungan pastoral. agar informasi yang diperoleh lebih lengkap dan lebih jelas dalam rangka pemecahan masalah sehingga dapat mencegah timbulnya masalah yang lain. (Storm 1999, p. 52). Perkunjungan bukan saja dilakukan di rumah jemaat, tetapi juga di rumah sakit ketika ada jemaat yang sedang dirawat di rumah sakit. Semuanya ini meneladani apa yang telah dilakukan oleh rasul Petrus, Kisah Para Rasul 9:23. Selain itu ada juga beberapa kunjungan lain seperti kunjungan ke Lembaga Pemasyarakatan dan yang terpenting yaitu mengunjungi janda-janda dan yatim piatu seperti ada tertulis: "Ibadah yang murni dan yang tak bercacat di hadapan Allah, Bapa kita, ialah mengunjungi yatim piatu dann jandajanda dalam kesusahan mereka, dan menjaga supaya dirinya sendiri tidak dicemarkan oleh dunia Yakobus 1:27." Dalam melakukan perkunjungan tentunya ada percakapan yang dilakukan antara hamba Tuhan dengan masyarakat yang dikunjungi. Dalam percakapan, seorang gembala harus menciptakan relasi yang baik agar jemaat yang menjadi lawan bicara merasakan tenang dan aman. Hal ini dapat tercipta ketika gembala memusatkan perhatiannya 
kepada persoalan dari teman bicaranya. Percakapan seperti ini disebut juga dengan komunikasi interpersonal. Komunikasi interpersonal merupakan komunikasi antara orangorang secara tatap muka, yang memungkinkan setia pesertanya menangkap reaksi orang lain secara langsung, baik secara verbal maupun non verbal. (Kalesaran, 2015, p. 5).

\section{Pendekatan Melalui Kegiatan Sosial}

Prinsip hidup seorang penginjil dalam pelayanan ialah selalu rendah hati, ramah tamah, bijaksana, dan jujur dalam melayani Tuhan. Selain dari itu, seorang penginjil dapat memuliakan Tuhan dengan harta yang mereka miliki dan dibagi-bagikan kepada orang miskin atau janda-janda yang membutuhkan. Dengan demikian, mereka dapat membuktikan kasih yang nyata melalui kehidupan sehari-hari. Lukas 18:22 mengatakan: "Mendengar itu Yesus berkata kepadanya: "Masih tinggal satu hal lagi yang harus kaulakukan: juallah segala yang kaumiliki dan bagikanlah itu kepada orang-orang miskin, maka engkau akan beroleh harta di sorga, kemudian datanglah kemari dan ikutlah Aku."

\section{Kesimpulan}

Berdasarkan hasil penelitian, dapat disimpulkan bahwa penginjilan dapat dilaksanakan di desa Rantau Buda khususnya orang-orang yang belum percaya. Adapun strategi yang dilakukan untuk menyampaikan Injil di tempat tersebut yaitu dengan pendekatan Pastoral Kontekstual melaluis berdoa dan berpuasa, pendekatan dengan pemerintah setempat, pengenalan kebudayaan, kunjungan pastoral, dan juga pendekatan melalui kegiatan sosial. Sebelum strategi itu dilakukan, seorang penginjil terlebih dahulu mengetahui sejarah berdirinya desa Rantau Buda, keadaan desa tersebut dan juga kegiatan-kegiatan yang sering dilakukan baik itu kegiatan sosial, budaya maupun agama. Artinya untuk menyampaikan Injil, seorang penginjl dapat berkontekstual dengan menyadari akan kekayaan tradisi budaya dan menekankan akan pengaruh-pengaruh modernisasi.

Mengingat begitu pentingnya Penginjilan, maka seorang penginjl dapat melakukan pola pendekatan yang tepat dan relevan, agar kebutuhan Injil dapat tersalurkan dengan baik. Seorang penginjil pun harus memiliki pemahaman rohani yang Alkitabiah sebagai dasar untuk membekali diri sebelum terjun ke lapangan pelayanan. Tujuan dari semuanya ini yaitu melaksanakan Amanat Agung Yesus Kristus yang terdapat dalam Matius 28:19-20. Ini merupakan tugas semua hamba Tuhan untuk menjangkau yang belum terjangkau. Dengan kata lain membawa orang-orang yang belum percaya agar mengenal dan tinggal di dalam Tuhan. Dengan demikian, strategi yang digunakan dapat dikatakan berhasil dengan menjadikan Amanat Agung yang disampaikan oleh Tuhan Yesus kepada murid-murid sebagai dasar dari pelayanannya. Orang-orang yang belum percaya di desa Rantau Buda, akhirnya menjadi percaya dan dapat membangun hubungan yang baik dengan Tuhan. 


\section{Daftar Rujukan}

Abineno, J. L. Ch. 1983. Aku Percaya Kepada Allah. Jakarta: BPK Gunung Mulia.

Abineno, J. L. Ch. 1998. Percakapan Pastoral Dalam Praktik. Jakarta: BPK Gunung Mulia.

Akal, Yuni Jones. 2002. Strategi Penginjilan Kota. Jakarta: Institusi Filsafat dan Kepemmpinan Jaffray Jakarta.

Atus, I. R. "Upacara Adat Suku Dayak Dusun Manunggul.” Elektronik (Handphone), March 14, 2019.

Beek, Aart Van. 2007. Pendampingan Pastoral. Jakarta: BPK Gunung Mulia.

Charles, Gerkin. 1992. Konseling Pastoral Dalam Transisi. Yogyakarta: Kanisius.

Dimas. "Kepercayaan Suku Dayak Dusun Manunggul." Elektronik (Handphone), March 11, 2019.

Djadi, Jermia, and Yoseph Christian Thomassoyan. "Kepemimpinan Yesus Kristus Menurut Injil Sinoptik Dan Relevansinya Terhadap Kepemimpinan Rohani Masa Kini.” Jurnal jaffray 9, no. 1 (april 3, 2011): 60-85.

Dumiwul. "Kepercayaan Mistis Dusun Manunggul." Elektronik (Handphone), April 12, 2019.

—. "Sejarah Desa Rantau Buda.” Elektronik (Handphone), March 3, 2019.

Eime, Leroy. 1982. Doa Bukan Sekedar Kata-Kata. Malang: Gandum Mas.

Harming, Harming. 2017. "Metode Penginjilan Yesus Dalam Injil Yohanes 4:1-42." Evangelikal: Jurnal Teologi Injili dan Pembinaan Warga Jemaat 1(2):162-69.

Harming, and Katarina. "Strategi Pelayanan Lintas Budaya Berdasarkan Markus 4:1-34." Evangelikal: Jurnal Teologi Injili dan Pembinaan Warga Jemaat 3, no. 1 (January 30, 2019): 113-121.

Kalesaran, Angie Indria. "Peranan Komunikasi AntarPribadi Pemimpin Pemuda Dalam Meningkatkan Minat Beribadah Pemuda GMIM Sion Warembungan.” E-journal “acta diurna" Volume IV. No.5. (2015): 5.

Nasir, Moh. 2005. Metode Penelitian. Bogor: Ghalia Indonesia.

Pattison, Stephen A. 1998. Critique Of Pastoral Care. London: SCM Press.

Pelem, P. 2019. "Kepercayaan Mistis Dusun Manunggul.”

Prince, Dereck. 1994. Doa dan Puasa. Yayasan Pekabaran Injil Immanuel.

Salmondia, S. 2020. "Data Statistik Penduduk."

Storm, M. Bons. 1999. Apakah Penggembalaan Itu? Jakarta: BPK Gunung Mulia.

Strong, James. t.t. "Strong's Exhaustive Concondance Of The Bible." 33.

Tjandra, Jimmy. 2009. Doa Yang Di Tolak Tuhan. Anggota IKAPI.

Tomatala, Yakob. 1996. Teologi Kontekstualisasi. Malang, Jawa Timur: Gandum Mas.

Tomatala, Yakob. 2002. Penginjilan Masa Kini Jilid 1. Malang: Gandum Mas.

Djadi, J., \& Thomassoyan, Y. C. (2011). Kepemimpinan Yesus Kristus Menurut Injil Sinoptik Dan Relevansinya Terhadap Kepemimpinan Rohani Masa Kini. Jurnal Jaffray, 9(1), 60-85. https://doi.org/10.25278/jj71.v9i1.91 
Duatan, D. (2016). Strategi Penginjilan Yang Efektif di Desa Rantau Buda Kalimantan Selatan. STT Petra, Samarinda.

Etam, K. (2015). Religi dan Peralatan Tradisional Suku Dayat Meratus di Kotabaru, Kalimantan Selatan. Balai Arkeologi Banjarmasin, 1, No. 1.

Harming, \& Katarina. (2019). Strategi Pelayanan Lintas Budaya Berdasarkan Markus 4:1-34. Evangelikal: Jurnal Teologi Injili Dan Pembinaan Warga Jemaat, 3(1), 113-121.

Kalesaran, A. I. (2015). PERANAN KOMUNIKASI ANTARPRIBADI PEMIMPIN PEMUDA DALAM MENINGKATKAN MINAT BERIBADAH PEMUDA GMIM SION WAREMBUNGAN. E-Journal “Acta Diurna”, Volume IV. No.5., 5.

Koentjaraningrat. (1993). Kebudayaan Mentalitas dan Pembangunan. Jakarta: PT Gramedia Pustaka Utama.

Moleong, L. J. (2017). Metodologi Penelitian Kualitatif. Bandung: PT Remaja Rosdakarya.

Nainggolan, B. D. (2016). Pemahaman Konsep dan Keterlibatan dalam Penginjilan Berdasarkan Matius 28:18-20. Jurnal Koinonia, 8(2), 35-70.

Nasir, Moh. (2005). Metode Penelitian. Bogor: Ghalia Indonesia.

Peter, G. W. (2006). A Biblical Th eology of Missions. Malang: Gandum Mas. 